\title{
General Commentary: Rethinking the role of animals in human well-being
}

\author{
Mark A. Oyama ${ }^{1 *}$ and James A. Serpell ${ }^{2}$ \\ ${ }^{1}$ Department of Clinical Studies - Philadelphia, Section of Cardiology, University of Pennsylvania, Philadelphia, PA, USA \\ ${ }^{2}$ Department of Clinical Studies - Philadelphia, Center for the Interaction of Animals and Society, University of Pennsylvania, Philadelphia, PA, USA \\ ${ }^{*}$ Correspondence: maoyama@vet.upenn.edu
}

Edited by:

Susan G. Simpson, University of South Australia, Australia

\section{A commentary on}

Effects of social support by a dog on stress modulation in male children with insecure attachment

by Beetz, A., Julius, H., Turner, D., and Kotrschal, K. (2012). Front. Psychol. 3:352. doi: 10.3389/fpsyg.2012.00352

Psychosocial and psychophysiological effects of human-animal interactions: the possible role of oxytocin

by Beetz, A., Uvnas-Moberg, K., Julius, H., and Kotrschal, K. (2012). Front. Psychol. 3:234. doi: 10.3389/fpsyg.2012.00234

Pet ownership and cardiovascular risk: a scientific statement from the American heart association

by Levine, G. N., Allen, K., Braun, L. T., Christian, H. E., Friedmann, E., Taubert, K. A., et al. (2013). Circulation 127, 1-11. doi: 10.1161/CIR.0b013e31829201e1

Recent reports highlight the emerging idea that ownership of companion animals can significantly affect human health: Two articles in Frontiers in Psychology report that dogs provided superior social support to children with disorganized attachment patterns than did other humans (Beetz et al., 2012a), and that the neuropeptide hormone oxytocin is likely involved in the formation of these human-animal bonds and their ability to protect or buffer us from the debilitating effects of stress (Beetz et al., 2012b). In 2013, the American Heart Association endorsed a Scientific Statement on pet ownership and cardiovascular disease risk, stating that pet ownership, and in particular that of dogs, should be considered as a means to reduce cardiovascular risk factors and improve survival in individuals with existing cardiovascular disease (Levine et al., 2013).
The belief that animals could influence human well-being is one that extends back thousands of years to when shamans or "witch doctors" could be called upon to induce either sickness or healing through the evocation of animal "guardian spirits". Since the late eighteenth century, companion animals have been used as agents of rehabilitation to treat social ostracism, loneliness, and recidivism of the mentally ill, chronically infirmed, and criminal, respectively. An expert none other than Florence Nightingale once remarked that a pet "is often an excellent companion for the sick, for the long chronic cases especially" (Nightingale, 1860). Thus, it could be said that humans have always suspected an ability of animals to improve the human condition. This premise has been applied in a wide variety of conditions including pervasive developmental and psychiatric disorders, victims of sexual abuse, dementia, fibromyalgia, and stroke (Dietz et al., 2012; Muñoz Lasa et al., 2013). The therapeutic potential in these and other disease conditions should not be overlooked.

There are more than 43 million households in the US that own one or more dogs and over half of US households own some species of pet (American Veterinary Medical Association, 2012). Sixty-three percent of these households regard their pets as full-fledged family members. Thus, pets, and the dog in particular, are ubiquitous members of our social environment. It is well-established that social support systems benefit patients with chronic diseases, and whether dogs can either fulfill or enhance this support structure merits additional study. We have previously hypothesized that the "salutary effect of social support should apply to any positive social relationship; any relationship in which a person feels cared for, loved, or esteemed" (Serpell, 2000). Despite the growing evidence that companion animals may contribute socially to human wellbeing, this field of investigation has still received very limited medical recognition. In 2011 consumers in the US spent over $\$ 230$ billion dollars for prescription drugs (National Health Expenditure Account, 2011). An equivalent cost-benefit analysis of pet ownership to improve wellbeing merits closer consideration. In the past, animals have been regarded as a test bed for new therapies or as models of human disease. We would encourage consideration of companion animals as therapy for disease. This premise deserves serious consideration by the mainstream medical community and research funding agencies.

\section{REFERENCES}

American Veterinary Medical Association. (2012). U.S. Pet Ownership and Demographics Sourcebook. Schaumburg: American Veterinary Medical Association.

Beetz, A., Julius, H., Turner, D., and Kotrschal, K. (2012a). Effects of social support by a dog on stress modulation in male children with insecure attachment. Front. Psychol. 3:352. doi: 10.3389/fpsyg.2012.00352

Beetz, A., Uvnas-Moberg, K., Julius, H., and Kotrschal, K. (2012b). Psychosocial and psychophysiological effects of human-animal interactions: the possible role of oxytocin. Front. Psychol. 3:234. doi: 10.3389/fpsyg.2012.00234

Dietz, T. J., Davis, D., and Pennings, J. (2012). Evaluating animal-assisted therapy in group treatment for child sexual abuse. J. Child Sex. Abus. 21, 665-683. doi: 10.1080/10538712. 2012.726700

Levine, G. N., Allen, K., Braun, L. T., Christian, H. E., Friedmann, E., Taubert, K. A., et al. (2013). Pet ownership and cardiovascular risk: a scientific statement from the American heart association. Circulation 127, 1-11. doi: 10.1161/CIR. 0b013e31829201e1

Muñoz Lasa, S., Máximo Bocanegra, N., Valero Alcaide, R., Atin Arratibel, M. A., Varela Donoso, E., and Ferriero, G. (2013). Animal assisted interventions in neurorehabilitation: 
a review of the most recent literature. Neurologia. doi: 10.1016/j.nrl.2013.01.012. [Epub ahead of print].

National Health Expenditure Account. (2011). Centers for Medicare and Medicaid Services, Office of the Actuary, National Health Statistics Group, US Department of Commerce, Bureau of Economic Analysis and U.S. Baltimore, MD: Bureau of the Census.

Nightingale, F. (1860). Notes on Nursing, What It is and What It is Not. New York, NY: Appleton.
Serpell, J. A. (2000). "Animal companions and human well-being: an historical exploration of the value of human-animal relationships," in Handbook on Animal-Assisted Therapy: Theoretical Foundations and Guidelines for Practice, ed A. Fine (Philadelphia, PA: Academic Press Elsevier), 3-19.

Received: 24 May 2013; accepted: 07 June 2013; published online: 25 June 2013.

Citation: Oyama MA and Serpell JA (2013) General Commentary: Rethinking the role of animals in human well-being. Front. Psychol. 4:374. doi: 10.3389/fpsyg. 2013.00374

This article was submitted to Frontiers in Psychology for Clinical Settings, a specialty of Frontiers in Psychology

Copyright (c) 2013 Oyama and Serpell. This is an openaccess article distributed under the terms of the Creative Commons Attribution License, which permits use, distribution and reproduction in other forums, provided the original authors and source are credited and subject to any copyright notices concerning any third-party graphics etc. 